\title{
Seismicity induced by hard coal mining in the vicinity of faults
}

\author{
Zbigniew Burtan*, Jerzy Cieślik and Dariusz Chlebowski \\ AGH University of Science and Technology, Faculty of Mining and Geoengineering, Cracow, Poland
}

\begin{abstract}
An inherent feature of Polish collieries within the Upper Silesia Coal Basin is the high level of mining induced seismicity, resulting in elevated rockburst hazard levels. One of the major causes of high-energy seismic events is that mining operations are continued in the vicinity of major faulting zones. The study summarises the results of geo-mechanical and statistical analysis of mining-induced seismic activity in the region of major faults, in a selected section within a colliery. Seismic activity assessment involves the categorisation of seismic events due to tectonic movements in the context of various face development systems with respect to the faulting zone: perpendicular (advancing towards the faulting zone or retreating) or parallel (along the faulting zone). Registered seismic activity was analysed in the context of epicenter locations and variations of seismic activity in relation to the developing face operations in the function of time and energy ratings (Gutenberg-Richter formulas). Results have demonstrated that increased levels of seismic activity in the strata can be attributable to mining operations in the vicinity of major faulting zones.
\end{abstract}

Keywords: hard coal mining, faults, induced seismicity

\section{Introduction}

The geomechanical and statistical analysis of mining-induced seismicity performed in preparing this paper assumes the form of a case study and covers the geological and mining conditions of one of the collieries of the former Katowicki Holding Węglowy S.A. company. The coal beds in the mining area of the selected colliery are found in three major tectonic blocks separating the respective mining sections ( $\mathrm{J}, \mathrm{K}$ and $\mathrm{L}$ ). The boundaries of these sections constitute fault zones V, VI, VII, VIII, Środkowy and Kłodnicki (Fig. 1) with various azimuths and throw amplitudes (KHW S.A. 2000-2014).

In mining to date, the highest rockburst hazard level was associated with the extraction of coal beds in parts $\mathrm{K}$ and $\mathrm{L}$ in the area of the Kłodnicki Fault and in part $\mathrm{J}$ in areas affected by mining events. Of the 19 rockbursts recorded since 1980, the majority (14) occurred near faults, where exploitation was conducted in the direct surroundings of extensive zones of mainly fault VI (Fig. 2) and the Kłodnicki Fault. In analysing the location of seismic foci related to mining within the area of tectonic disturbances, it is difficult to clearly determine

\footnotetext{
* Corresponding author: burtan@agh.edu.pl
} 
whether a specific seismic event is actually the effect of fault activation and its influence, or the collapse of rigid roof strata. The results of the seismic moment analysis might provide some insight, as the mechanisms occurring alongside faults are mainly connected with shearing $[1,2]$. Unfortunately, there is a shortage of such data and they are not available for every seismic event. Seismic events are usually considered as located within faults, related to fault activation, or to a certain extent connected with the presence of faults when the hypocentral distance of their focus from the edge of the fault is no longer than $150 \div 200 \mathrm{~m}$ (Fig. 2), although such distances are assumed only on the basis of experiences and intuitions regarding the specific (local) conditions of mining. In regional scale, the relations were established between major faults locations and occurring of strong seismic events [3].

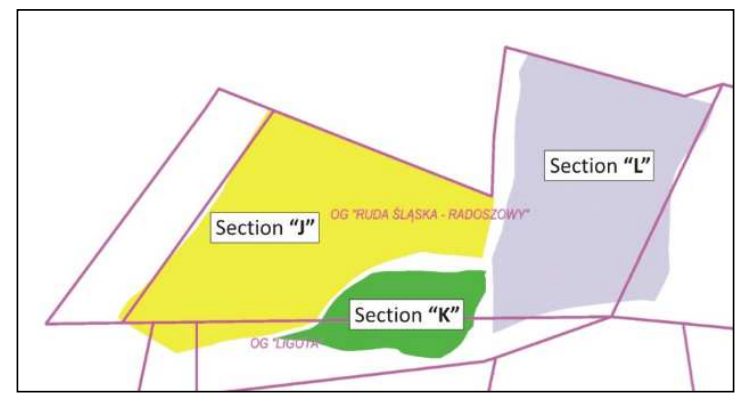

Fig. 1. The colliery's mining area by mining parts J, K, L.

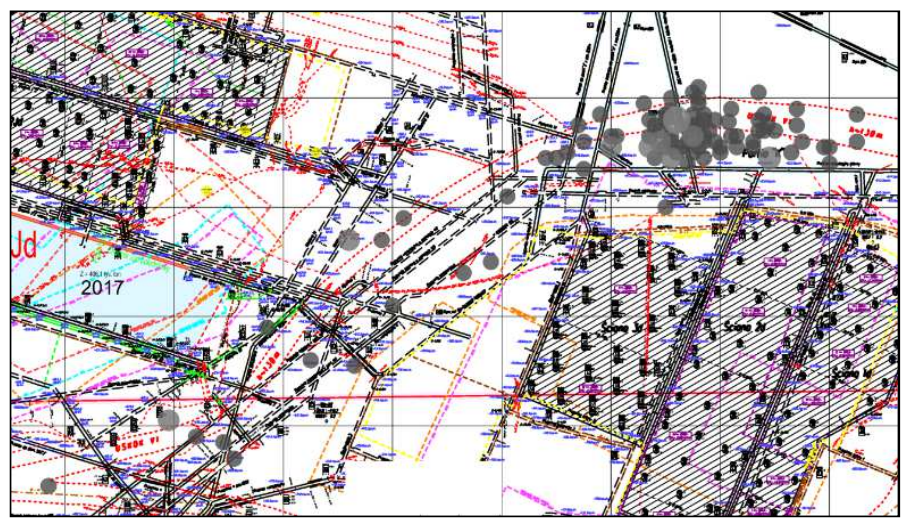

Fig. 2. Location of seismic foci $\left(\geq 10^{5} \mathrm{~J}\right)$ resulting from the activation of fault VI.

In the context of rockburst prevention, it would be valuable, for specific geological and mining conditions, to determine the distance between the longwall face and the rupture surface of the fault which increases the probability of seismic events connected with the activation of the latter. However, due to the complexity of this problem, it might prove impossible to find a solution based on analytical and numerical calculations. An attempt to determine such distances was made in the course of analysing data from the selected colliery's mining geophysics station on seismic activity observed during the mining of four longwalls of coal bed 502/1 in part K. The study was based on the authors' previous experience regarding the locations of seismic foci during mining operations [5], where the vast majority of seismic events occurred in front of the mining face. Such regularities were also confirmed in other studies [6-9].

The analysis demonstrated that for every specific mining face a group of seismic events can be found which are directly connected with the influence of faults through the anomalous location of their foci in front or behind the wall front. Using this methodology, it is also 
possible to determine the extent and the critical distance between the mining face and fault edge at which its activation might occur. An analysis of the mining data demonstrates that the anomalies of seismic foci location is observed both when the face is retreating from and advancing towards the fault or moving along the faulting zone. The results of anomalous location analyses were verified using Gutenberg-Richter (GR) distribution [10], which confirmed the different nature of seismic activity in the designated ranges of fault zones.

\section{Seismic activity analysis during the mining of coal bed 502/1 in part $\mathrm{K}$}

The analysis was based on the data on the scale of seismic activity during the mining of bed $502 / 1$ in part K, which was delimited on three sides by the Kłodnicki, VI and VII faults with throws ranging from 75 to $220 \mathrm{~m}$ (Fig. 3). Coal bed 502/1 with the thickness of $8 \mathrm{~m}$ was mined on two strata, from top to bottom with a cave-in and the presented data concern mining operations in the first stratum, which was associated with considerably greater seismic activity than mining in the second stratum. The roof of the coal bed was composed of shale, arenaceous shale and fine-grained sandstone. The floor was largely composed of fine-grained sandstone and shale formations. The mining operations in the analysed area were conducted on four exploitation front - EF1, EF2, EF3 and EF4 (Fig. 3). EF1 was mined along fault VII, retreating from the Kłodnicki Fault and advancing towards fault VI. EF2, EF3 and EF4 were exploited from the Kłodnicki Fault towards fault VI. Table 1 presents the profile of seismic activity during mining operations on coal bed 502/1 in part $\mathrm{K}$ with regard to the consecutively selected longwalls EF $1 \div \mathrm{EF} 4$.

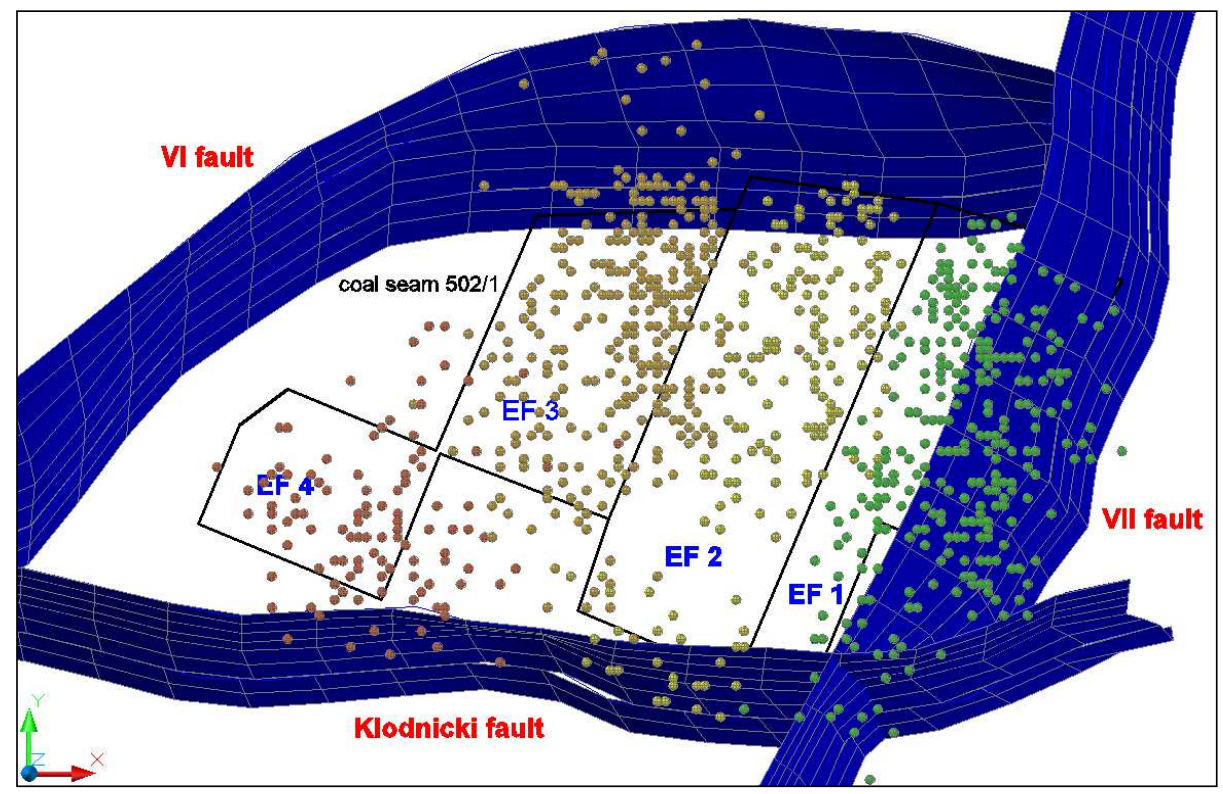

Fig. 3. Fault geometry and the location of seismic foci with an energy $>1 \cdot 10^{5} \mathrm{~J}$ during the mining of longwalls EF1, EF2, EF3 and EF4 in part K of bed 502/1.

Perpendicular distances from the seismic foci to the mining face and to the fault edge were calculated on the basis of the coordinates of foci locations during the exploitation of individual longwalls and the current mining face location in relation to the fault line. Vector calculus was used in the calculations [11]. 
Table 1. Seismic activity during the exploitation of coal bed 502/1 in part $\mathrm{K}$.

\begin{tabular}{|c|c|c|c|c|c|c|c|}
\hline \multirow{2}{*}{ Longwall } & \multirow{2}{*}{ Year } & \multicolumn{5}{|c|}{ Number of seismic events in energy intervals [J] } \\
\cline { 3 - 8 } & & $10^{3}$ & $10^{4}$ & $10^{5}$ & $10^{6}$ & $10^{7}$ & Total \\
\hline EF1 & $1997-2000$ & 982 & 270 & 36 & 3 & 0 & 1496 \\
\hline EF2 & $1997-2000$ & 795 & 147 & 18 & 1 & 0 & 1263 \\
\hline EF3 & $2002-2003$ & 1399 & 266 & 61 & 7 & 0 & 2105 \\
\hline EF4 & $2005-2006$ & 573 & 97 & 18 & 3 & 0 & 826 \\
\hline
\end{tabular}

\subsection{An analysis of seismic events locations relative to the fault}

Fig. 4 and Fig 5. illustrate the correlations between the distances of seismic foci for seismic events recorded during the operation of wall EF1 from the line of the Kłodnicki Fault and from the line of fault VI, respectively, based on the runway of the mining face. The positive values of seismic event distances (on the y axis) mean that the seismic event was located outside the fault zone and negative values mean that the seismic focus was located on the fault (at a maximum distance of $200 \mathrm{~m}$ from its line). EF1 began its run $15 \mathrm{~m}$ from the line of the Kłodnicki Fault and ended $70 \mathrm{~m}$ from the line of fault VI with a runway of $655 \mathrm{~m}$. In accordance with the adopted $200 \mathrm{~m}$ criterion, the ranges marked with the red vertical line were identified with the fault's range of influence.

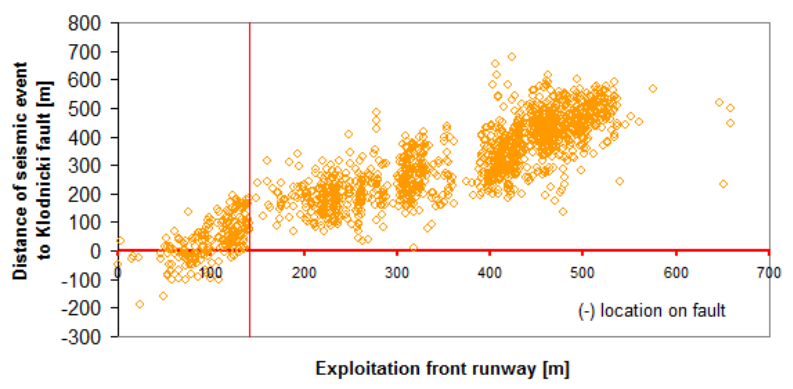

Fig. 4. Distance of seismic event to the line of the Kłodnicki Fault based on runway length.

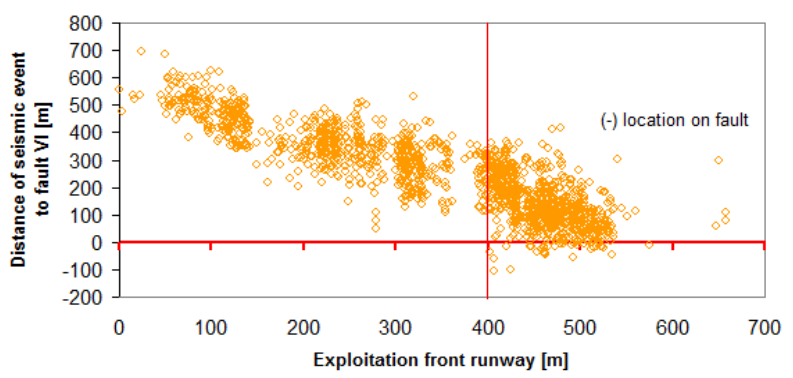

Fig. 5. Distance of seismic event to the line of fault VI based on runway length.

In accordance with the methodology adopted for EF1, the range of influence can be estimated as $\sim 140 \mathrm{~m}$ for the Kłodnicki Fault and $\sim 300 \mathrm{~m}$ for fault VI. 


\subsection{An analysis of seismic events locations relative to the mining face}

The next stage involved an analysis of the seismic event locations relative to the EF1 mining face to determine whether the focus was in front (positive distance value) or behind the mining face (negative distance value) (Fig. 6). These analyses were performed for all seismic energy intervals. As observed [5], ca. $75 \%$ of seismic events during mining operation are located in front of the mining face.

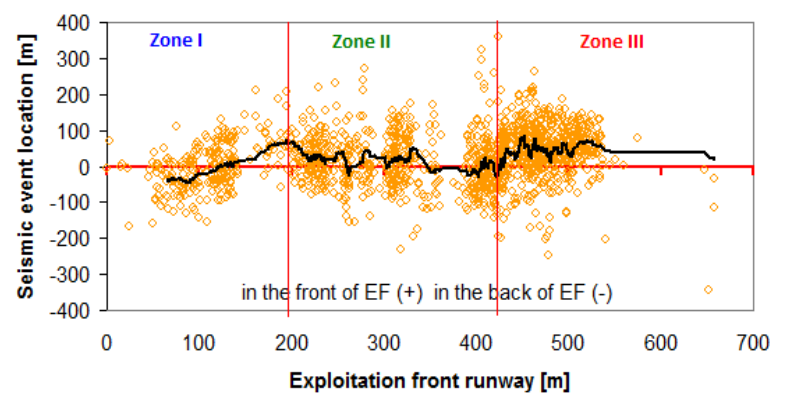

Fig. 6. The variation of seismic event locations in front of and behind the face during the operation of EF1.

The analysis demonstrated that at the initial run of EF1, most seismic foci were located behind the mining face. As it developed (and the runway became longer), the percentage of events located in front of the face was increasing; for a runway of $150 \mathrm{~m}$ the moving average with 30 seismic events (Fig. 6 - black line) assumed only positive values. The distance for which the rising trend in this correlation changes is marked with a red vertical red line (Zone I), which is assumed as an estimated boundary of the range of influence of the Kłodnicki fault on the seismic activity during the mining operations in EF1. In Zone II a similar number of seismic events was recorded in front of and behind the mining face or at a small distance from it. For higher runway lengths during advance towards fault VI, another anomaly occurs, i.e. the number of seismic events with foci located in front of the mining face increases. The beginning of this trend, marked with a second red vertical line, is assumed as the boundary of the range of influence of fault VI on the seismic activity values during the mining operation of EF1 (Zone III). Following the adopted methodology, the range of influence of the Kłodnicki Fault for the mining operation of EF1 can be estimated as $\sim 185 \mathrm{~m}$, and $\sim 320 \mathrm{~m}$ for fault VI.

On the basis of the analysed data regarding the seismic activity recorded during the mining operation of EF1, an attempt was made to present the correlations between the seismic energy of individual seismic events and the distance of the seismic focus to the Kłodnicki Fault and fault VI (Fig. 7 and Fig. 8). The presented distributions do not indicate a correlation between seismic event energy and the distance of the focus to the line of the fault, which means that the seismic events related to fault activity have a similar energy as other seismic events.

Qualitatively similar trends can also be observed for data obtained during the mining of

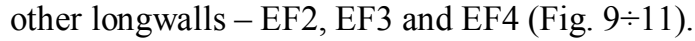

Following the adopted methodology, for the mining operation of EF2 both the range of influence of the Kłodnicki Fault and fault VI can be determined as $\sim 150 \mathrm{~m}$, for EF3 the range of influence of fault VI was $\sim 230 \mathrm{~m}$, and for EF4 the range of influence of the Kłodnicki Fault was $\sim 150 \mathrm{~m}$. The combined ranges of influence obtained for individual mining faces are listed in Table 2. 
The highest values obtained for the range of influence of faults during the mining operation of EF1 could result from mining along fault VII, and in the case of EF3 the influence of the presence goaves in the previously extracted EF2 wall.

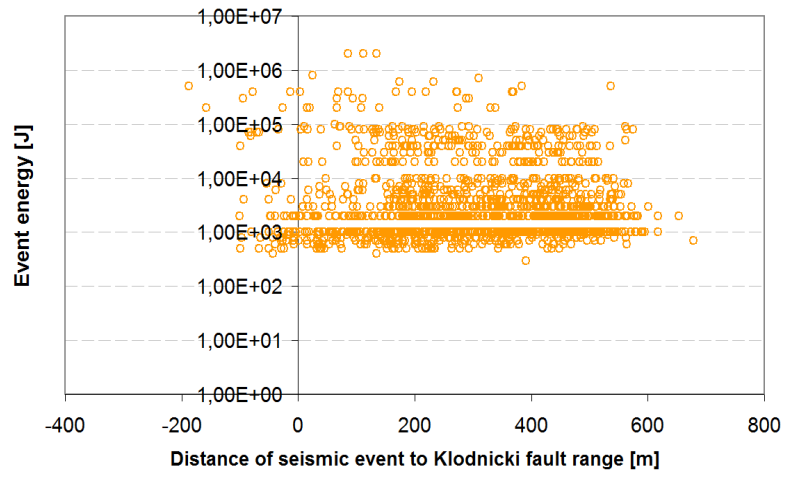

Fig. 7. The energy distribution of individual seismic events along with their distance to the Kłodnicki Fault.

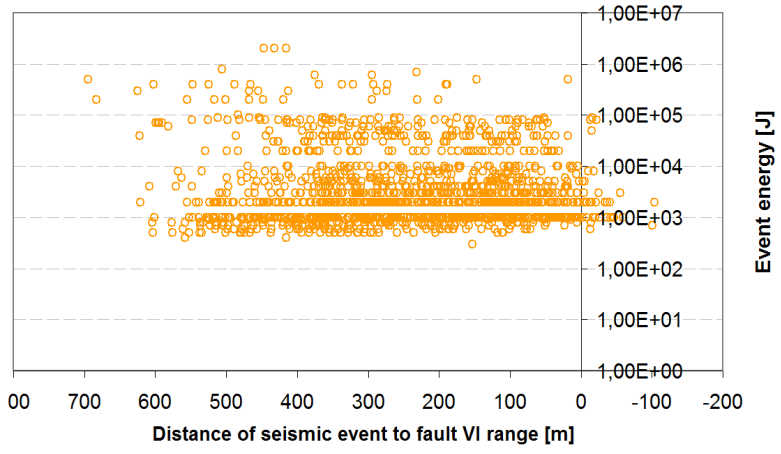

Fig. 8. The energy distribution of individual seismic events along with their distance to fault VI.

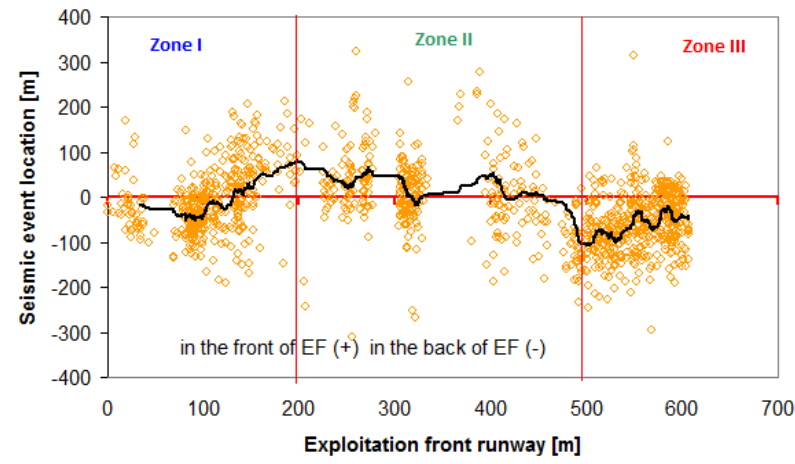

Fig. 9. The variation of seismic event locations in front of and behind the wall during the operation of EF2. 


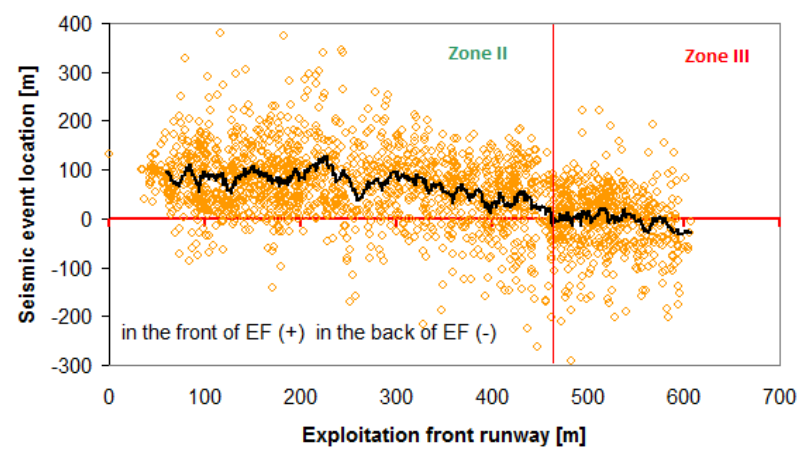

Fig. 10. The variation of seismic event locations in front of and behind the wall during the operation of EF3.

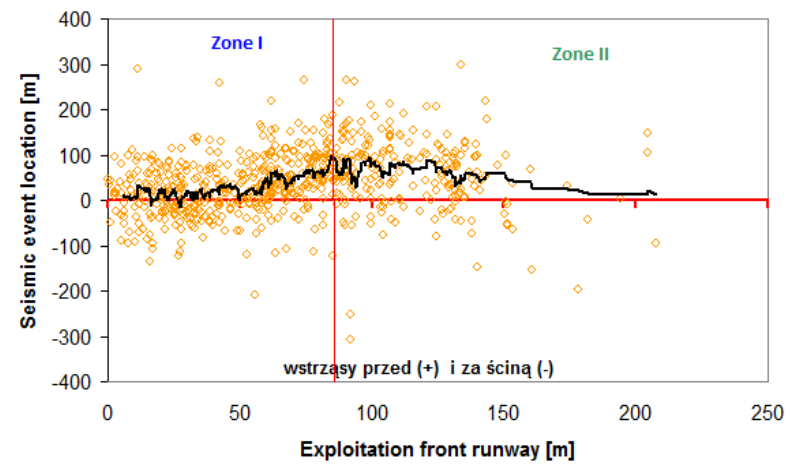

Fig. 11. The variation of seismic event locations in front of and behind the wall during the operation of EF4.

Table 2. The range of influence of faults on seismic activity for individual mining faces.

\begin{tabular}{|c|c|c|}
\hline Longwall & Kłodnicki fault range $[\mathrm{m}]$ & Fault VI range $[\mathrm{m}]$ \\
\hline EF1 & 140 & 300 \\
\hline EF2 & 150 & 150 \\
\hline EF3 & - & 230 \\
\hline EF4 & 150 & - \\
\hline
\end{tabular}

\section{Seismic activity analysis using Gutenberg-Richter distribution}

Important data on the magnitude of seismic hazard is provided by the Gutenberg-Richter distribution (the distribution of seismic energies) [10] used in seismology, which describes the correlation between the number of seismic events recorded in respective energy classes and the value of the seismic energy emitted.

$$
\log N=a-b \log A_{s}
$$

where $N$ means the number of seismic events with an energy $A_{s}$ and $a$ and $b$ are distribution parameters $a$ is a measure of seismic activity level and $b$ describes the relative correlation between the number of strong seismic events and the number of weak seismic events. The 
lower value of $b$ (slope), and therefore lower line steepness $(\mathrm{b}=\operatorname{tg} \alpha)$ described by GutenbergRichter distribution, indicating a greater percentage of strong seismic events, is a sign of greater seismic hazard levels, and, in consequence, the dynamic events threat affecting underground workings. Using the Gutenberg-Richter distribution to compare seismic activity from various periods and mining regions facilitates the evaluation of variations in seismic hazard levels, including activity changes with regard to the range of occurrence of highmagnitude events. Figs. $12 \div 15$ present Gutenberg-Richter distributions and the equations describing them for seismic events with seismic energies $A_{s} \geq 10^{3} \mathrm{~J}$ recorded during the mining operation of EF1, EF2, EF3 and EF4 in coal bed 502/1, part $\mathrm{K}$, for designated extraction zones relative to faults, and the parameters of those distributions are listed in Table 3.

Table 3. GR parameters distribution for longwalls EF1, EF2, EF3 i EF4 in coal bed 501/ part K.

\begin{tabular}{|c|c|c|c|}
\hline \multirow{2}{*}{$\begin{array}{c}\text { Exploitation } \\
\text { front }\end{array}$} & \multirow{2}{*}{ Zone number } & \multicolumn{2}{|c|}{ Gutenberg-Richter parameters } \\
\cline { 2 - 4 } & & $\mathrm{a}[-]$ & $\mathrm{b}-]$ \\
\hline \multirow{3}{*}{$\begin{array}{c}\text { Exploitation } \\
\text { front EF1 }\end{array}$} & Zone I & 3.63 & 0.47 \\
\cline { 2 - 4 } & Zone II & 5.15 & 0.73 \\
\cline { 2 - 4 } & Zone III & 5.40 & 0.76 \\
\hline \multirow{3}{*}{$\begin{array}{c}\text { Exploitation } \\
\text { front EF2 }\end{array}$} & Zone I & 4.03 & 0.58 \\
\cline { 2 - 4 } & Zone II & 5.13 & 0.78 \\
\cline { 2 - 4 } & Zone III & 5.58 & 0.85 \\
\hline \multirow{2}{*}{$\begin{array}{c}\text { Exploitation } \\
\text { front EF3 }\end{array}$} & Zone II & 5.13 & 0.70 \\
\cline { 2 - 4 } & Zone III & 5.59 & 0.73 \\
\hline \multirow{2}{*}{$\begin{array}{c}\text { Exploitation } \\
\text { front EF4 }\end{array}$} & Zone I & 6.64 & 1.18 \\
\cline { 2 - 4 } & Zone II & 4.47 & 0.59 \\
\hline
\end{tabular}

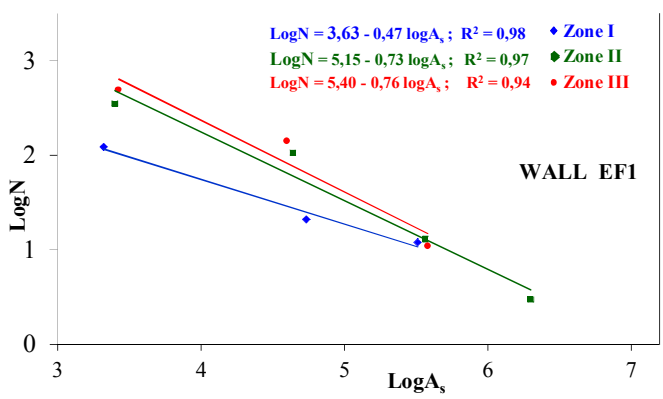

Fig. 12. GR parameters for longwall EF1 in coal bed 502/1 part K.

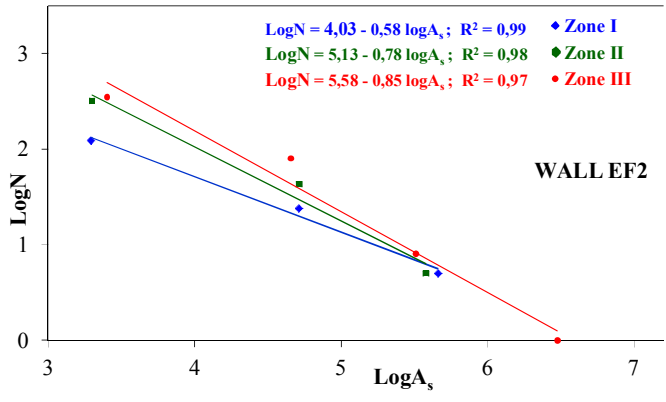

Fig. 13. GR parameters for longwall EF2 in coalbed 502/1 part K. 


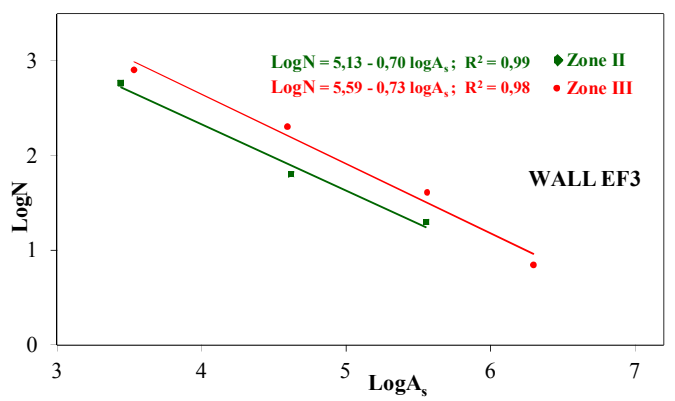

Fig. 14. GR parameters for longwall EF3 in coalbed 502/1 part K.

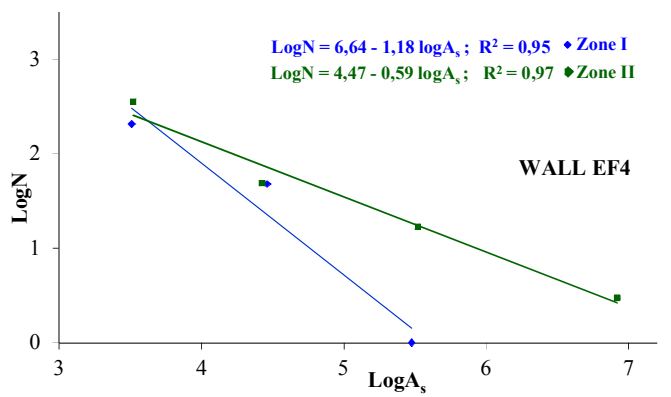

Fig. 15. GR parameters for longwall EF4 in coalbed 502/1 part K.

On the basis of the presented parameter distributions and values for respective fronts selected in coal bed 502/1, part $\mathrm{K}$, it can be concluded that there are significant variations in Gutenberg-Richter distributions in relation to specific zones designated in previous analyses. It can also be observed that:

- for EF1, EF2 and EF3 correlations are present at individual mining stages; at stage I the seismic hazard level measured by the value of the $\boldsymbol{a}$ parameter is the lowest, and at stage III it is the highest,

- for EF1 and EF2 at stage I and for EF1, EF2 and EF3 at stages II and III there is a similar percentage of strong and weak seismic events measured by the value of the $\boldsymbol{b}$ parameter (lower at stage I and higher at stages II and III), which might indicate that there are different mechanisms behind most seismic events occurring at stage I and those occurring at stages II and III,

- for EF4 there are inverse correlations at stages I and II relative to EF1, EF2 and EF3.

\section{Summary}

The presented correlations of the influence of selected discrete tectonic faults on seismic activity during mining operations within coal bed 502/1, part $\mathrm{K}$ (using the example of a selected mine of the former KHW S.A.) determine the range, i.e. the distance of the exploitation front from the line of the Kłodnicki Fault and fault VI, at which the influence of those tectonic dislocations on the intensity of seismic events can be recorded. The most similar distances found in the course of range of influence analysis for specific fronts were obtained for the Kłodnicki Fault $(\sim 140 \div 150 \mathrm{~m})$. In the case of fault VI, it had a greater range of influence $(\sim 150 \div 300 \mathrm{~m})$, which, for EF1, might have resulted from mining along fault VII, and for EF3, from the presence of goaves in the extracted EF2. The obtained relationships 
and range values might prove useful in designing rockburst prevention measures used for performing mining operations in fault zones.

Nevertheless, the adopted methodology for determining the range of influence of a fault on seismic activity based on seismic event locations in front of/behind the exploitation front requires further study and verification on a larger number of cases of mining operations under restricted tectonic and mining conditions.

The paper was prepared within AGH-UST statutory research, No 11.11.100.005

\section{References}

1. Ł. Rudziński, G. Lizurek, Mechanizm zjawiska sejsmicznego oraz tapnięcia w O/ZG Rudna w Polkowicach z 19.03.2013 r. z wykorzystaniem lokalnych i regionalnych sieci Cuprum (Seismic event mechanism and rockbursts in O/ZG Rudna in Polkowice on 19 March 2013 using local and regional Cuprum networks), Czasopismo NaukowoTechniczne Górnictwa Rud 3, 61-72 (2015) (In Polish)

2. G. Kwiatek, Acta Geophys. 52, 2, 155-171 (2004)

3. E. Pilecka, Z. Pilecki, Analysis of relation between induced seismic activity and satelite data. $19^{\text {th }}$ Symposium on Application of Geophysics to Engineering and Environmental Problems SAGEEP, EEGS, 2-6 April 2006, Seattle, USA, 346-355. (2006)

4. E. Pilecka, Z. Pilecki, The changes in lineaments locations in the zones of seismicity induced by mining. Proc. $13^{\text {th }}$ European Meeting of Environmental and Engineering Geophysics “Near Surface 2007”, EAGE, 3-5 Sept. 2007, Istanbul, Turkey, (2007) (Electronic document)

5. J. Cieslik, Z. Burtan, D. Chlebowski, A. Zorychta, Journal of Sustainable Mining 16, 3, 94-103 (2017) doi: 10.1016/j.jsm.2017.10.002

6. M. Kozłowska, Ilościowa analiza odległości epicentralnych wstrząsów względem frontu eksploatacji w O/ZG Rudna (LGOM) (Quantitative analysis of epicentral tremor distance in relation to exploitation front in O/ZG Rudna LGOM), Przegląd Górniczy 68 (12) 75-85 (2012) (In Polish)

7. M. Kozłowska, Acta Geophys. 61, 5, 1156-1169 (2013) doi: 10.2478/s11600-013-0137$\mathrm{X}$

8. J. Dubiński, Z. Pilecki, W. Zuberek, Badania geofizyczne w kopalniach-przeszłość, teraźniejszość, i zamierzenia na przyszłość (Geophysical research in mines - past, present and future plans) Wyd. IGSMiE PAN, Kraków (2001) (in Polish)

9. Z. Pilecki, Zastosowanie rejonowej obserwacji sejsmoakustycznej do kontroli stanu zagrożenia tapaniami (The use of zonal seismoacustic observations for rock burst hazard monitoring). Publs. Inst. Geophys. Pol. Acad. Sc. Series M, M-16, 245, 203-216 (In Polish)

10. B. Gutenberg, C. F. Richter, Seismicity of the Earth and Associated Phenomena, 2nd ed. Princeton University Press., New York (1954)

11. M. Paluch, Matematyka bezstresowa $w$ życiu codziennym $i$ technice (Non-stress mathematics in everyday life and technology), Agencja wydawniczo-poligraficzna ArtTekst, Kraków (2015) (In Polish)

12. Report, Kompleksowe projekty eksploatacji pokładów zagrożonych tapaniami (Comprehensive mining projects in coal beds threaten by rockbursts), KHW S.A. KWK „WS”, Katowice, (unpublished material) (2014) (In Polish) 